\title{
Effects of Combined training strength and endurance on serum levels of homocysteine in elderly inactive woman
}

\author{
Behmardi $\mathrm{T}^{1}$, Banitalebi $\mathrm{E}^{2}$, Ghafari $\mathrm{M}^{* 3}$
}

\begin{abstract}
Introduction and purpose: The purpose of this study was to investigate the effects of different combined training (strength and endurance) on serum levels of homocysteine in elderly inactive woman.

Materials and Methods: This study was a quasi-experimental research, 40 Retired elderly woman of education (Age: $60.34 \pm 0.82$ year, High: $155 \pm 0.01 \mathrm{~cm}$, Weight: $71.72 \pm 1.89 \mathrm{~kg}$ ) were select purposely and randomly place into four groups, strength + endurance $(S+E)(n=10)$, endurance + strength $(E+S)(n=9)$, circulation combined $(\mathrm{CI})(\mathrm{n}=12)$ and control $(\mathrm{n}=9)$ groups. Serum levels of homocysteine were measured before and 48 hours after the last training session. Training program done eight week, 3 times per week. Within-group differences were analyzed by paired samples t-test and the between-group differences were analyzed by one-way ANOVA.

Findings: after 8 weeks of combined training, in each of the three experimental groups had a significant reduction in weight, BMI and percent body fat and fasting blood glucose $(\mathrm{P} \leq 0.05)$ and had a significant reduction in serum levels of homocysteine in $\mathrm{S}+\mathrm{E}$ group $(\mathrm{P} \leq 0.05)$. In between-group differences there are significant difference in weight $(\mathrm{p}=0 / 017)$ and $\mathrm{BMI}(\mathrm{p}=0 / 023)$ and no significant difference in levels of homocysteine $(\mathrm{p}>0 / 05)$.

Conclusion: According results, it seems, combined training strength + endurance by reducing the levels of homocysteine can be a method of prevention of cardiovascular disease in elderly women may be recommended.
\end{abstract}

Keywords: Combined training, homocysteine, aging

Received: 2016/02/21

Accepted: 2016/05/24

Copyright () 2018 Quarterly Journal of Geriatric Nursing.This is an open-access article distributed under the terms of the Creative Commons Attribution international 4.0 International License(http://creativecommons.org/licenses/by /4.0/) which permits copy and redistribute the material, in any medium or format, provided the original work is properly cited.

1 - MA of Exercise Physiology, Department of Physical Education, Yasouj Branch, Islamic Azad University, Yasouj, Iran

2 - Assistant Professor, Department of Physical Education, Faculty of Literature and Humanities, Shahrekord University, Shahrekord, Iran

3 - PhD student of Exercise Physiology, Department of Physical Education, Faculty of Literature and Humanities, Shahrekord University, Shahrekord, Iran. (Corresponding Author):E-mail: ghafari.mehdi@gmail.com 


\section{تاثير تمرينات تركيبى قدرتى و استقامتى بر سطوح سرمى هموسيستئين در زنان سالمند غير فعال}

طوبى بهمردى '، ابر اهيم بنى طالبى '، مهدى غفارى "َ**

تاريخ دريافت مقاله: تاريخ يذيرش مقاله: ع/ س/ هوسו

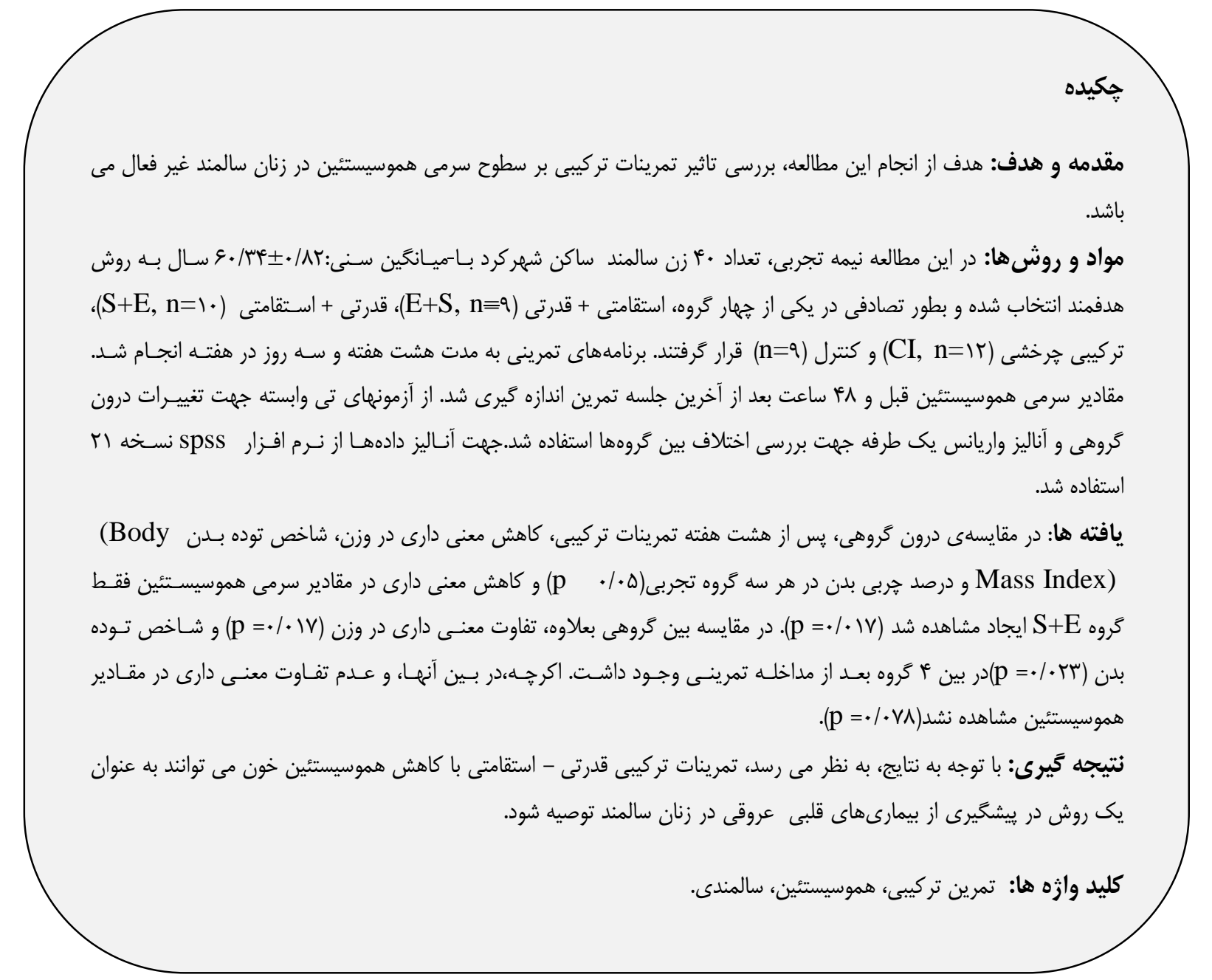

1- كارشناس ارشد فيزيولوزى ورزش، گروه تربيت بدنى، واحد ياسوج، دانشخاه آزاد اسلامى، ياسوج، ايران

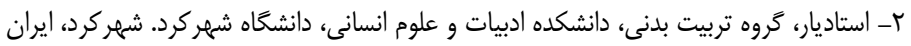

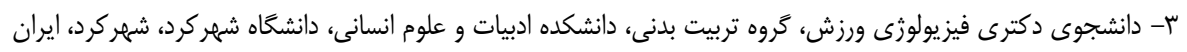
(نويسنده مسؤول). يست الكترونيكى: ghafari.mehdi@gmail.com

v. 
هموسيستئين در ييشخيرى از بيمارىهـاى قلبـى عروقى اهميـت

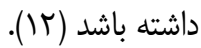

جهت بررسى تاثير فعاليت بدنى بر عوامل خطرساز قلبى عروقى، برخى مطالعات از انجام فعاليتهـاى هـوازى نظيــر دويــن نـرم و سبك، كوهنوردى، يياده روى طولانى مدت، شنا و غيره (سا, عI) تمرينات قدرتى حمايت مى كنند (1) ). در-تحقيقـات انجـام شـده نشان داده شده است كه تمرينات بلند مدت هوازى موجب كاهش سطح هموسيستئن مى شود. رانديواو همكاران (T. . T) تـأثير ماه تمرينات منظه هوازى (دويدن روى تردميـل) را بـر روى ال زن جوان با اضافه وزن و داراى سندرم تخمدان يلى سيستيك بـر كـاهش هموسيسـتئين كـل پلاسـما مشـاهده كردنـد (أl). در تحقيقى ديخر، \& ماه برنامه ورزشى بر سـطح هموسيسـتئين مـورد بررسى قرار گرفـت. نتـايج نشـان داد كـه تمـرين ميتوانـــــــح هموسيستئين را كاهش دهد (أl). همجِنين وينسـنت و همكـاران

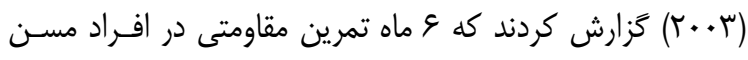

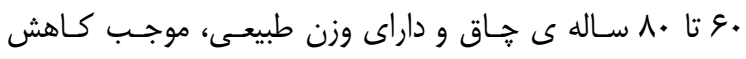
هموسيستئين سرم مى شود (ه). به علت اختصاصى بـودن آثار تمرين قدرتى و استقامتى در سطح هموسيسـتئين، تركيـب هـر دو نوع تمرين براى عملكرد بدنى مطلوب و سلامتى در افراد سـالمند توصـيه شــده اسـت (ع)). تركيـب همزمـان تمـرين اسـتقامتى و مقاومتى در برنامههاى تمرينى منظه، تمرين تركيبى ناميـده مسى شود. در خصوص تمرينات تركيبـى بـر عوامـل خطـر سـاز قلبـى عروقى به خصوص هموسيستئين تحقيقات كمى موجـود اسـت . Subaş1
بيمارىهاى قلبى عروقى مهمترين بيمارى دوران سـالمندى هسـتند. در ايران بيماريهاى قلبى عروقى، يكـى از بيماريهـاى شـايع و علـت اصلى مركى و مير مى باشد (1). در تحقيقات انجام شـده در خنــــ سال اخير، در بين عوامل خطر ساز قلب و عــروق، هموسيسـتئين يك عامل خطرساز جدى شـناخته شـده اسـت، كـه حتى آن را شاخص بروز سكته قلبى ناميده اند؛ به طوريكـهـ افـزيش سـطح هموسيستئين، با افزايش خطر ابتلا به بيماريهاى مربوط به شريان سرخركى نظير تصلب شرائين همراه اسـت (أl-r) .هموسيسـتئين اسيد آمينه واسطه مسير سوخت و سـاز بــنـ از اسـيد آمينـه غيـر

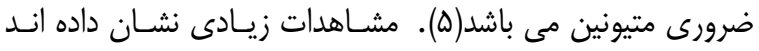
كاهش سطح هموسيستئين باعث كاهش حمـلات قلبى و سكته مى شود (َّ, و). مستندات موجود،ارتباط قوى بـين سـكته قلبى و افزايش سطح هموسيستئين تاييد نموده اند (V). بطوريكه، افززايش ه ميكرو مول در ليتر در سـطح هموسيسـتئين تـام بـا هو درصـــ ريسك بيمارىهاى قلبى عروقى در مـردان و •^ درصــ در زنـان همراه است. غلظت هموسيستئين ارتباط مثبتى با سن دارد (^). به ازاى هر • ب سال افـزايش سـن، غلظـت هموسيسـتئين بـه طـور متوسط ץ/1 ميكرومول در ليتر بالا مى رود(9). در زنان يائسه نيـز غلظت هموسيستئين بالاتر از دوران ييش از يائسكى است (•(1). به طور كلى، سبك زندگى سالم با كاهش خطر بيماريهـاى قلبى عروقى ارتباط دارد (1). فعاليت ورزشى منظم ممكن است با تاثير بر عوامل خطر سنتى از قبيل خاقى، فشار خون و نيم رخ لييبدى و يا-عوامل خطر جديد از قبيل فعاليت فيبرينوتيك و غلظتهاى 
مبتلا شدن به بيمارى خاص و يا هر كونه مداخلهى درمـانى مـؤثر

بر نتايج آزمايشَاهى بـود. بــر اسـاس ملاكهـاى ورود و خـروج از

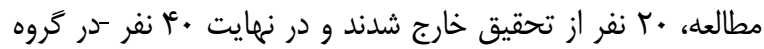
تمرين استقامتى + قدرتى (n=9)، قـدرتى + اسـتقامتى (•) (n=)،

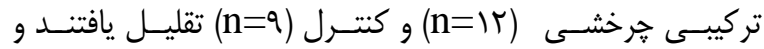
برنامههاى تمرينى را به مدت 1 هفته به پايان رساندند.

كليهى شـركت كنــــان، فـرم رضـايتنامه را پـس از آَكاهى از

جزئيات مطالعه حاضر امضا نمودند. يزوهش حاضر زير نظر يزشك متخصص و متخصصان فيزيولوزى ورزشى انجام گرديد. كليسىى

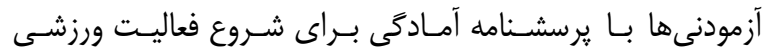
و (Physical Activity Readiness Questionnaire) يرسشنامه يِيشينه پزشكى را قبل از شروع مطالعه تكميـل نمودنـد. در ضمن آزمودنىها در طى يك جلسه با نحوهى انجام فعاليـت ورزشى آشنا شدند. تحقيق حاضر از نوع نيمه تجربى با سه گروه تمرينى و يك كنترل با ييش آزمون و يس آزمون مى باشد. اطلاعات مربوط به تحقيـق به صورت ميدانى و آزمايشَاهى گَردآورى گَرديـد. قبـل از شـروع تمرين و ^^ץ ساعت بعد از آخرين جلسه تمرينـى قـد، وزن، درصــ קربى بدن و شاخص توده بدن آزمودنىها اندازه گيرى شد. اندازه گيرى وزن افراد با لباس سبك، بدون كفش و با ترازوى ديجيتال

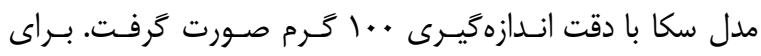
محاسبه درصد جربى بدن، ابتدا ضخامت جربـى زيــر يوسـتى سـه نقطهاى سه سربازو، روى ران و فوق خاصره آزمودنىها با استفاده از روش جين يوستى كاليير (با دقت //• ميلىمتر) در سمت راست بدن اندازهيرى شده و سيس با استفاده از فرمول درصدهربى بدن
استقامتى تغيير معنى دارى در ميزان هموسيستئين و نيمرخليييـدى زنــان و مـردان مشــاهده نكردنـــ (IV). در تحقيـق فرامـرزى و

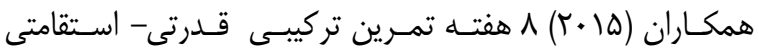
نتوانست كاهش معنى دارى در غلظت هموسيستئين ايجـاد نمايـــ (1)(1). مير و همكـاران در اثـر 1 هفتـه تمـرين تركيبـ هـوازىـ-

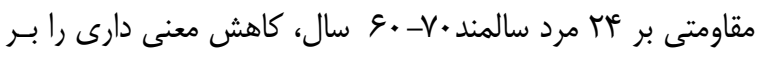
سطوح هموسيستئين در تروه تركيبى مشاهده كرد (•r). با توجه به افزايش بيمارىهاى قلبى عروقى، تحقيقـات بيشـترى براى درك بهتر اثر روشهاى مختلف تمرينى بر عوامـل خطرسـاز

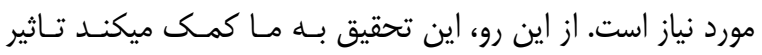
تمرينات تركيبى مختلـف قــرتى واسـتقامتى بـر سـطوح سـرمى هموسيستئين را در زنان سالمند غير فعال بررسى كنيه.

\section{مواد و روشها}

جامعلى آمارى اين يثوهش رازنان سالمندسالم غيرفعال مقـيم در شهرستان شهر كرد تشكيل د دادند. يٍ از دعوت بـه همكـارى بـاــا

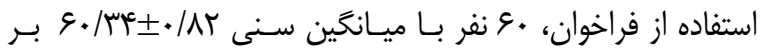
اساس شاخصهاى ورود به تحقيق و به صورت هدفمنــ انتخـاب شدند. وبه طور تصادفى به جهار كروه تمرين اسـتقامتى +قـدرتى

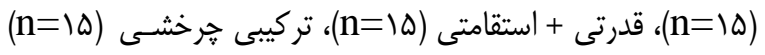
و كنترل (D=10) تقسيم شدند. ملاكىهاى ورود به مطالعه شامل عدم مصرف هر نـوع دارو، عـدم ابتلا به بيمارى هاى مزمن، نداشتن سابقه فعاليت بــنى مـنظمه در يك سال قبل از آغاز يزوهش و داشتن سلامت عمومى جسـمانى بود. ملاكىهاى خروج از مطالعه شامل غيبت بيش از سه جلسه يـاـ 


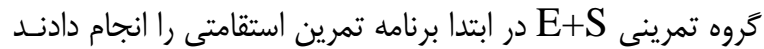

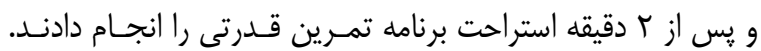
كروه تمرينى S+E در ابتدا برنامه تمرين قدرتى و پِ از r دقيقه

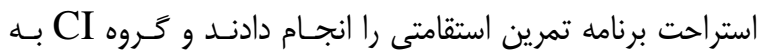
صورت هرخشى برنامه تمرينى E+S+E+S+E+S را انجـام دادند، بدين صورت كه برنامه قدرتى به سه قسمت و زمان برنامـهـ استقامتى هم به سه قسمت تقسيم شد (Tr). ֶِ از با ساعت ناشتايى شبانه آزمودنىها رأس سـاعت 9 صـبح در محل آزمايشگاه تخصصى حضور يافتند و نمونه خون اوليـه بـهـ

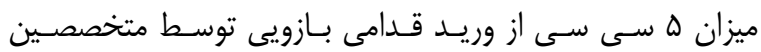

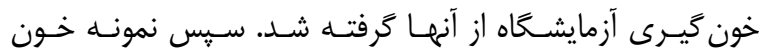
سانتريفوز شده و نمونه سرمى آن جدا شد و براى آنـاليز در دمـاى

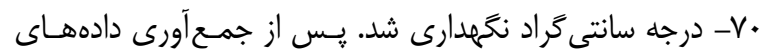
اوليه، برنامه تمرين از روز بعد بـه مـــت 1 هفتـه در محـل سـالن ورزشى آغاز شد. بعد از اتمـام دوره تمـرين، يـس از ^أ سـاعت از آخرين جلسهى تمرين مجدداً انــازهخيــى هــاى آنترويومتريسك و آزمايشگاهى در شرايط و زمان آزمونهاى اوليه و بــا همـان ابـزار توسط محقق و متخصص آزمايشكاه انجام يذيرفت. اندازه گيـرى غلظت هموسيسـتئين بـا اسـتفاده از كيـت تخصصى و بـا روش The enzyme-linked ( سـنش ايمنسى مـرتبط بـا آنزيم immunosorbent assay يس از كسب اطمينـان از نرمـال بــودن توزيـع دادههـا بـا آزمــون كولموكروف- اسميرنوف از آزمون تى وابستهـ، بــراى بررسـى اثر تغييرات درون كَروهى و از آزمون آناليز واريـانس يـك طرفـه اثـر تغييرات بين گروهى استفاده شد و در صورت معنى دارى از آزمون
محاسبه شد. همجنين درصدجربى هر نقطه سه مرتبه و به صورت קرخشى اندازمگيرى شد (19). قد افراد در وضعيت ايستاده و بدون كفش درحالى كه كتفها در شرايط عادى قرار داشتند، با استفاده از متر نوارى انعطاف يذير استاندارد اندازه گيرى شد. تست آمادگى جسمانى انتخاب شده براى اين مطالعه، شاخص توده بدن بود كـهـ از تقسيم وزن بر حسب كيلـوًرم بـهـ مجـذور قـد برحسـب متـر محاسبه شد. برنامههاى تمرينى به مدت 1 هفته از تمرينات ساده به مشكل و از شدت كم به شدت بالا بـا در نظركـرفتن اصـل اضـافه بـار و افزايش شدت تمرين بود. هر جلسه شامل •ا دقيقـه گـرم كـردن عمومى و •ه دقيقه تمرين و •ا دقيقه سردكردن بـود. برنامـهى تمرينى استقامتى شامل كار برروى دوخرخه كارسنج با شـدت او درصد حـداكثر ضـربان قلب (Maximum Heart Rate) بـــ

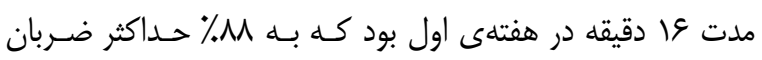
قلب به مدت •r دقيقه درهفتهى هشتم رسيد. همجنين در رابطه با كنترل شدت تمرين، اين كار با تعيين ضربان قلب آزمـودنىهـا قبل از شروع تمرينات، حين اجرا و پِ از انجام فعاليـت در هـر جلسه توسط يزوهشكَران با استفاده از ضربان سـنج يـولار كشـور فنالد انجام شد(·r). برنامهى تمرينى مقاومتى شامل يرس سينه، جلوران، پشت ران، كشش زير بغل، جلو بازو و كشش دو طرفه به "اييين در بركيرندهى عضلات بزرگ بـالا تنسه و يـايين تنـه بـود.

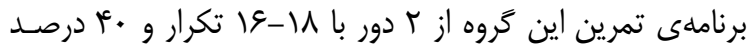

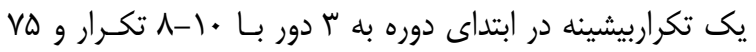
درصد يك تكرار بيشينه و با استراحتهاى r دقيقـه اي در پايـان دورهى تمرينى رسيد(·r, (T). 


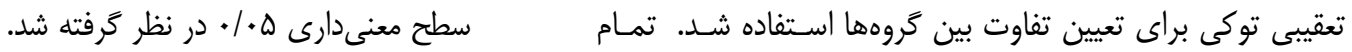
عمليات آمارى تحقيق با استفاده از نرم افزار SPSS نسـخه آ و

نتايج اين تحقيق كه حاصل از 9 نفر در گروه Co S+E+S از هشت هفته تمرين تركيبى در جدول ا ارائه شده است.

جدول شمارها : مقايسه تغييرات در متغيرهاى اندازه تيرى شده قبل و بعد از هشت هفته مداخله تمرينى

\begin{tabular}{|c|c|c|c|c|c|}
\hline \multicolumn{2}{|c|}{$\mathbf{p}$} & \multicolumn{2}{|c|}{ انحراف معيار 土 ميانكَين } & \multirow[t]{2}{*}{ كروه ها } & \multirow[t]{2}{*}{ متغير } \\
\hline بين كَروهى & درون گَروهى & يس ت آزمون & ي يش آزمون & & \\
\hline \multirow[t]{4}{*}{$+1+1 V *$} & $* * / \cdots \Delta$ & $V T / V V \pm F / q V$ & 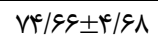 & $\mathrm{E}+\mathrm{S}$ & \multirow{4}{*}{ 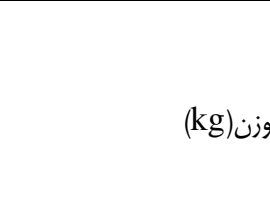 } \\
\hline & $* \cdot / \cdot r$ & $\varepsilon N / \varepsilon \cdot \pm r / N \varepsilon$ & $V \cdot / \Lambda \cdot \pm r / q$. & $\mathrm{S}+\mathrm{E}$ & \\
\hline & $* * 1 \cdots$ & $s Y / 4 I \pm Y / 44$ & $9 \varepsilon / 41 \pm r / \varepsilon q$ & $\mathrm{CI}$ & \\
\hline &.$/ 01$ & $V \varepsilon / 99 \pm 4 / \cdot \Delta$ & $\vee \varepsilon / \Lambda \Lambda \pm r / v \wedge$ & $\mathrm{CO}$ & \\
\hline \multirow{4}{*}{ 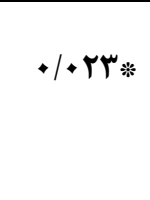 } & $* \cdot 1+\infty$ & $r q /|r \pm| / r \mid$ & $r q / \wedge q \pm 1 / r$. & $E+S$ & \multirow{4}{*}{$\begin{array}{r}\text { شاخص توده بدن (BMI) } \\
\left(\mathrm{kg} / \mathrm{m}^{2}\right.\end{array}$} \\
\hline & $* \cdot / \cdot r$ & $r N / r \cdot \pm I / \Delta S$ & $r q / r \mu \pm 1 / v)$ & $\mathrm{S}+\mathrm{E}$ & \\
\hline & $* \cdot \cdots$ & $r \& / V G \pm \cdot / N G$ & $r V / \Delta V \pm \cdot / 9 T$ & CI & \\
\hline & . /Ft. & 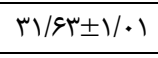 & 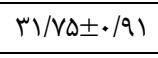 & $\mathrm{CO}$ & \\
\hline \multirow[t]{4}{*}{$+1+1$} & $* / \cdots$ & $r \varepsilon / q . \pm 1 / 4 r$ & $r \cdot /<q \pm 1 / .$. & $E+S$ & \multirow{4}{*}{$\begin{array}{r}\text { جربى } \\
(\%)\end{array}$} \\
\hline & $* \cdot 1 \cdots$ & $r V / V V \pm I / r$. & 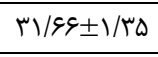 & $\mathrm{S}+\mathrm{E}$ & \\
\hline & $* * 1 \cdots$ & $r V / M \pm \cdot / 9 \Delta$ & $r \cdot \mid \varepsilon \Delta \pm 1 / \cdot \Delta$ & CI & \\
\hline & $\cdot / \cdot 1$ & $r V / \Delta \cdot \pm 1 / \cdot \cdot$ & $r N / D \cdot \pm \cdot / q T$ & $\mathrm{CO}$ & \\
\hline \multirow[t]{4}{*}{$+1+V \Lambda$} &.$/ 4 q$. & $r \mu / r \pm \cdot / r \Lambda$ & $r \mu / \varepsilon \Lambda \pm \cdot / v q$ & $E+S$ & \multirow{4}{*}{$\begin{array}{r}\text { هموسيستئين } \\
(\mathrm{m} \mu / \mathrm{L})\end{array}$} \\
\hline & $* \cdot 1 \cdot 1 \mathrm{~V}$ & $r T / \& H \pm \cdot / \& \Lambda$ & $T F / V q \pm \cdot / V \varphi$ & $\mathrm{S}+\mathrm{E}$ & \\
\hline & •/Aץ. & $r m / / r \pm \cdot / \kappa q$ & $r M / Y \Psi \pm \cdot / N T$ & $\mathrm{CI}$ & \\
\hline & .1 .94 & $r \backslash / \Lambda \Lambda \pm \cdot / \& Y$ & $r r / q \cdot \pm \cdot / \Lambda$. & Con & \\
\hline
\end{tabular}

E+

طور متناوب، CO CO آزمودنيهايى كه در برنامـه تمرينسى شـركت

$$
\text { نكردند، }
$$

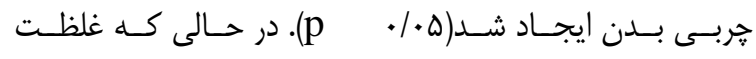

هموسيســتئين فقـــ در خــروه S+E كــاهش معنــــدارى

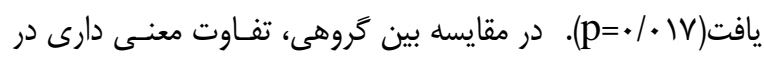

S ابتدا تمرين استقامتى بعـد تمـرين قـدرتى، S+E: S ابتــا

تمرين قدرتى بعد تمرين استقامتى، CI : قدرتى - اسـتقامتى بـــ

بر اساس يافتههاى يُوهش حاضر در مقايسهى درون گروهـى، در هر سه كروه تجربى كاهش معنى دارى در وزن، BMI و درصد 
هموسيستئين بعد از به كار بردن ^ هفته تمرين تركيبى (هـوازى)+

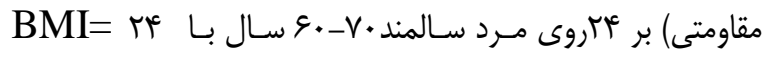
كزارش نمودند.-برنامه تمرينى هوازى شامل هر هفته ب جلسـهـ بـــ مدت •r دقيقه با شدت •V- •و درصد MHR و برنامـه تمـرين

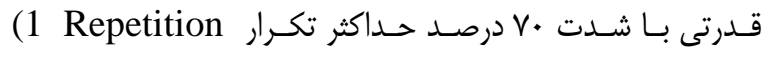
بود. علت بدست آمدن نتايج مختلف را مى تـوان Maximum) به تفاوت در يروتكلهاى تمرينى، مدت، شدت، نوع ورزش و البته سطح آمادگى هر شخص عنوان كرد (ع). ورزش منظهم نقش مهمى در كاهش بيماريهاى قلبى عروقى ايفـا مى كند(Y-TV). اگر خه مكانيسم ارتباط بين سطح هموسيستئين و خطرات بيماريهاى قلبـى عروقى، هنـوز مشـخص نيست، امـا افـزايش هموسيســتئين بواسـطه ى اخـتلال و آسـيب در سـلول LDL اندوتليال، افزايش خسبندگى ڤِلاكت، افزايش اكسيداسيون و رسوب در ديواره شريان و فعال سازى مستقيم روند لختـه شــن خون به عنوان القاى آترواسكلروز و ترومبوتيك يذيرفته شده است

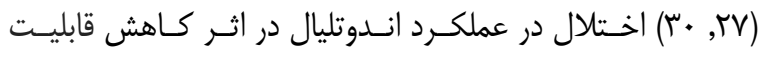
دسترسى بـهـ نيتريــ اكسـيد انـدوتليال و هموسيسـتئين بـالا رخ ميدهد-(آ). اثر ييشكيرانه ورزش مربوط به افزايش توليد نيتريـى اكسيد (افزايش فعاليـت و محتـواى يـروتئين) توسـط سـلولهـاى اندوتليال عروقى و جلوَّيرى از اختلال در عملكرد انـدوتليال مسى باشد. در أ هفته اول تمرين ورزشى، گثادى وابسته بــه انـدوتليوم باعث افزايش در ميزان دسترسى به نيتريك اكسيد مى شود. يكى

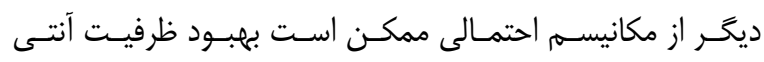
اكسيدانى عروق با تمـرين ورزشـى باشــ (rV) Choobineh و

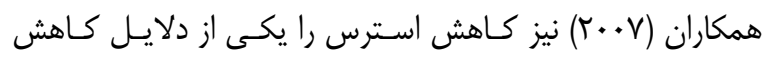

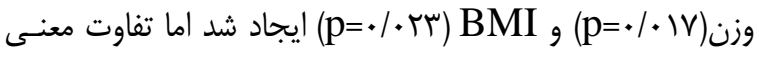
دارى در درصد هربى بلن و هموسيستئين ايجاد نشد(ه •/ > p). در مقايسه بين گروهى، آزمون توكى، تفاوت معنسى دارى بـين دو كروه ه ارتبـاط بـا متغييـر وزن و تفـاوت معنسى دارى بـين دو كـروه CI

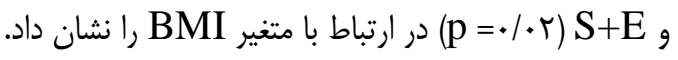

\section{بحث و نتيجه كيرى}

بر اساس يافتههاى يزوهش حاضر، 1 هفته تمرين تركيبى مختلف منجر به كاهش در ميزان هموسيستئين سرمى زنـان سـالمند غيـر فعال نشد. نتايج اين يزوهش اگرجه با يافتههاى بعضى از مطالعات

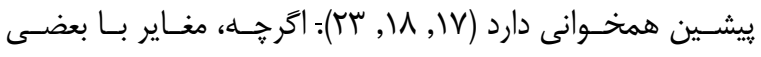
مطالعات ديخر مى باشد (זب- (צץ).

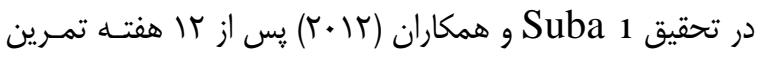
مقاومتى و استقامتى زير بيشينه (VD درصد ضربان قلب هدف) بـر ^ب فــرد جــوان تغييـر معنـى دارى در ميـزان هموسيســتئين و نيمرخهاى ليييدى زنـان و مـردان مشـاهده نشـد (IV). همجنـين فرامـرزى و همكـاران (أوسا) تـاثير ^ هفتـهـ تمـرين تركيبسى (

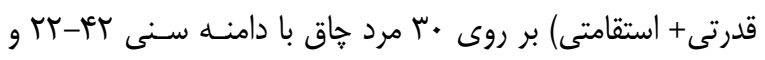
BMI بررسى نمودند. ، هر جلسـهـ تمـرين شـامل: זו- +1 تمرين قدرتى ايستخاهى با شدت •^-•• درصد 1RM و در انتها

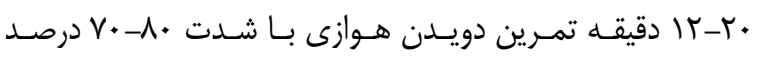
حداكثر ضربان قلب MHR بود.ولى اين برنامه تمرينى نتوانسـت غلظت هموسيستئين را بطـور معنسى دارى كـاهش دهـــ(1). در حاليكـه، ميــر و همكــاران كـاهش معنـى دارى را بــر سـطوح 
دليل غلظت سرمى هموسيستئين در كـروه S+E كـاهش معنى

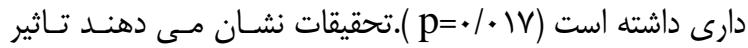
فعاليت ورزشى بر سطح هموسيستئين ميتواند تحت تاثير آمـادگى فردى و ميزان ياسخ بدن به استرس وارده باشــ(36) بنـابراين، نـوع فعاليـت بـدنى و ميـزان آن تـاثير مسـتقيمى بـر تغييـرات هموسيستئين خون دارد.

در مجموع نتايج اين تحقيق نشان داد، تمـرين تركيبـ مسىتوانـــ تاثير مثبتى بر وزن و شاخص توده بدنى در زنان سالمند غير فعـال داشته باشد. اگر خـهـ در ايـن مطالعـه تغييـر معنسـدارى در ميـزان هموسيستئين سرم مشاهده نشد اما، به نظر مسى رسـد، تمرينـات تركيبى قـدرتى + اسـتقامتى بـا كـاهش در ميـزان هموسيسـتئين ميتواند به عنوان يكى روش در ييشـخيرى از بيمـارىهـاى قلبـى عروقى در زنان سالمند توصيه شود. البته براى بررسى آثار بايدارتر و مشخصتر اين نوع تمرينات نياز به مطالعات كسترده تر بـا دوره

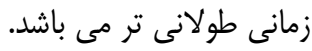

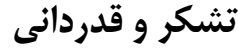

نغارندكان مقاله بر خـود لازم ميدانــــــــــ از تمـامى سـالمندان شركت كننده كه انجام اين تحقيق بدون وجود آنها ميسر نبـود، تشكر و قدردانى نمايند.
هموسيستئين پِ از تمرينات منظم اكسايشى بيان كردند بعلاوه، تمرينات ورزشى منظم نياز واكنشهاى متابوليكى نوسازى و ترميم بافت عضلانى را افزايش مى دهد. و متيونين هم كـه يـك اسـيد آمينه است افزايش نياز به آن براى توليد انـرزى و سـنتز هـروتئين باعث كاهش غلظت آن مى شود و بدين ترتيب، هموسيستئين نيز كه يكى از مواد واسطه اي متابوليسن متيونين است، كـاهش مى يابد (سٓ). همجنين عدم كنترل برخى رزيم غذايى، مصرف سيكار، وراثت و... امكان دارد بر عدم معنـادارى غلظـت هموسيسـتئين در

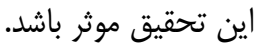
Cooper هموسيستئين با و هفته برنامه ورزشى هوازى نكردند(بس). به نظـر مـى رســــــــت تمرينـى بــراى نشــان دادن تغييـردر ســطح هموسيستئين بسيار كوتاه مى باشد. در مطالعه ديخرى هيج تغييرى در سطح هموسيستئين يس از IV هفته(Y جلسه در هفتـه) تمـرين

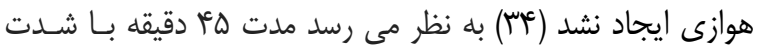
متوسط براى اعمال تغييرات در هموسيستئين كافى نيست. محققين بيان كردنـد كـه بكـاركيرى مــاخلات ورزشسى، سـطح هموسيستئين را در افراد هييرهموسيستئين در مقايسه بـا افـراد بـاـا

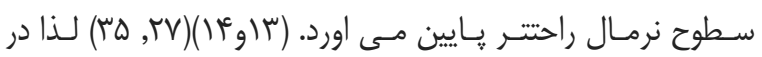
مطالعــهـ حاضـــر، عـــدم تغييـــر قابــل ملاحظـــهـ در ميــزان هموسيستئين،ممكن است به دليـل سـطوح نرمـال آن در شـركت كنندكان باشد. همانطور كه مسى دانسيم بــا افـزايش سـن، سـطح هموسيستئين بالا رفته كه مى تواند با افزايش شدت بيمارىهـاى قلبى و عروقى همراه باشد. بنابراين،احتمالا اثربخشى برنامه هـاى تمرينى بستخى به سطح پايه هموسيستئين نيـز دارد. بـهـ همـين 


\section{- References}

1. Azizi, Mirmiran, Azadbakht. Predictors of cardiovascular risk factors in Tehranian adolescents: Tehran Lipid and Glucose Study. International journal for vitamin and nutrition research. 2004;74(5):307-12.

2. Benedini S, Caimi A, Alberti G, Terruzzi I ,Dellerma N, La Torre A, et al. Increase in homocysteine levels after a half-marathon running: a detrimental metabolic effect of sport? Sport Sciences for Health. 2010;6(1):35-41.

3. Antoniades C, Antonopoulos AS, Tousoulis D, Marinou K, Stefanadis C. Homocysteine and coronary atherosclerosis: from folate fortification to the recent clinical trials. European heart journal. 2009;30(1):6-15.

4. Wierzbicki AS. Homocysteine and cardiovascular disease: a review of the evidence. Diabetes and Vascular Disease Research. 2007;4(2):143-9.

5. Finkelstein JD. Homocysteine: a history in progress. Nutrition Reviews. 2000;58(7):193204.

6. Subasi SS, Gelecek N, Ozdemir N, Ormen M. Influences of acute resistance and aerobic exercises on plasma homocysteine level and lipid profiles. TURKISH JOURNAL OF BIOCHEMISTRY-TURK BIYOKIMYA DERGISI. 2009;34(1):9-14.

7. Refsum M, H, Ueland M, PM, Nygård M, O, Vollset M, Dr. PH, SE. Homocysteine and cardiovascular disease. Annual review of medicine. 1998;49(1):31-62.

8. Kelley G, Kelley K. Effects of exercise and physical activity on homocysteine in adults: a meta-analysis of randomized controlled trials. J Exercise Phys. 2008;11(5):12-23.

9. Bostom AG, Jacques PF, Liaugaudas G, Rogers G, Rosenberg IH, Selhub J. Total homocysteine lowering treatment among coronary artery disease patients in the era of folic acidfortified cereal grain flour. Arteriosclerosis, thrombosis, and vascular biology. 2002;22(3):48891.

10. Andersson A, Brattström L, Israelsson B, Isaksson A, Hamfelt A, Hultberg B. Plasma homocysteine before and after methionine loading with regard to age, gender, and menopausal status. European journal of clinical investigation. 1992;22(2):79-87.

11. Eckel RH, Jakicic JM, Ard JD, De Jesus JM, Miller NH, Hubbard VS, et al. 2013 AHA/ACC guideline on lifestyle management to reduce cardiovascular risk: a report of the 
American College of Cardiology/American Heart Association Task Force on Practice Guidelines. Journal of the American College of Cardiology. 2014;63(25_PA.(

12. Prerost M, Feldman B, Herbert W. Homocysteine, fibrinogen and physical activity in human males with coronary artery disease. Comparative Haematology International. 1999;9(1):25-30.

13. Ali A, Mehra MR, Lavie CJ, Malik FS, Murgo JP, Lohmann TP, et al. Modulatory impact of cardiac rehabilitation on hyperhomocysteinemia in patients with coronary artery disease and “normal” lipid levels. The American journal of cardiology. 1998;82(12):1543-5.

14. Randeva HS, Lewandowski KC, Drzewoski J, Brooke-Wavell K, O'Callaghan C, Czupryniak L, et al. Exercise decreases plasma total homocysteine in overweight young women with polycystic ovary syndrome. The Journal of Clinical Endocrinology \& Metabolism. 2002;87(10):4496-501.

15. Vincent KR, Braith RW, Bottiglieri T, Vincent HK, Lowenthal DT. Homocysteine and lipoprotein levels following resistance training in older adults. Preventive cardiology. 2003;6(4):197-203.

16. Coffey VG, Hawley JA. The molecular bases of training adaptation. Sports medicine. 2007;37(9):737-63.

17. Subaşı SS, Gelecek N, Aksakoğlu G, Örmen M. Effects of two different exercise trainings on plasma homocysteine levels and other cardiovascular disease risks. Turkish Journal of Biochemistry/Turk Biyokimya Dergisi. 2012;37(3.(

- Emamdoost S, Faramarzi M, Bagheri L, Otadi K, Razaghi Naeeni E, Yazdani T, et al. The effect of concurrent resistance and aerobic training on serum level of homocysteine and lipid profile in overweight men. Scientific Journal of Kurdistan University of Medical Sciences. 2015;20(1):80 .-

19. Swisher AK, Yeater R, Moffett K, Baer L, Stanton B. A comparison of methods to determine body fat in individuals with cystic fibrosis: A pilot study. Journal of Exercise Physiology. 2003;6:105-13.

20. TANG Q-h, XIE X-r. Research of the physical function and fitness of elder intellectuals by health qigong. baDuanJin $[\mathrm{J}]$. Journal of Physical Education Institute of Shanxi Teachers University. 2008;1:043.

21. Cadore E, Pinto R, Lhullier F, Correa C, Alberton C, Pinto S, et al. Physiological effects of concurrent training in elderly men. International journal of sports medicine. 2010;31(10):689. 
22. Di Blasio A, Gemello E, Di Iorio A, Di Giacinto G, Celso T, Di Renzo D, et al. Order effects of concurrent endurance and resistance training on post-exercise response of non-trained women. Journal of sports science \& medicine. 2012;11(3):393.

23. Bahram ME, Najjarian M ,Sayyah M, Mojtahedi H. The effect of an eight-week aerobic exercise program on the homocysteine level and VO2max in young non-athlete men. KAUMS Journal (FEYZ). 2013;17(2):149-56.

24. Rashid Lamir A. The effects of 8 weeks aerobic exercise on levels of homocysteine, HSCRP serum and plasma fibrinogen in type II diabetic women. Life Science Journal. 2013 (ISI);10,430-435.

25. BIJEH N, EBRAHIMI AA, JAAFARI M. The effect of three months aerobic exercise on levels of hsCRP, homocysteine ,serum lipids and aerobic power in healthy and inactive middle aged men. 2012; 19, 98 (5).

26. Mir E, Fathei M, Sayeedi MM, Hejazi K. The effect of eight weeks combined training (erobic-resistance) on homocysteine, c-reactive protein and lipid profile in inactive elderly men. Medical Journal of Tabriz University of Medical Sciences and Health Services. 2015;36(6):80-6. 27. Hayward R, Ruangthai R, Karnilaw P, Chicco A, Strange R, McCarty H, et al. Attenuation of homocysteine-induced endothelial dysfunction by exercise training. Pathophysiology. 2003;9(4):207-14.

28. Mora S, Cook N, Buring JE, Ridker PM, Lee I-M. Physical activity and reduced risk of cardiovascular events potential mediating mechanisms. Circulation. 2007;116(19):2110-8.

29. Donnelly JE, Blair SN, Jakicic JM, Manore MM, Rankin JW, Smith BK. American College of Sports Medicine Position Stand. Appropriate physical activity intervention strategies for weight loss and prevention of weight regain for adults. Medicine and science in sports and exercise. 2009 - $\quad$ :( ) ;

30. Vincent HK, Bourguignon C, Vincent KR. Resistance training lowers exercise-induced oxidative stress and homocysteine levels in overweight and obese older adults. Obesity. 2006;14(11):1921-30.

31. Kothekar MA. Homocysteine in cardiovascular disease: A culprit or an innocent bystander? Indian journal of medical sciences. 2007;61(6):361. 
32. Choobineh S, Dabidiroshan V, Gaeini A. Effect of two training method of continuous and interval aerobic training on HS-CRP in wistar rats. J movement science \& sport. 2007;5(9):1-13. 33. Cooper A, Kendrick A, Stansbie D, Sargent D, West J. Plasma homocysteine in sedentary men: influence of moderately intense exercise. Journal of Cardiopulmonary Rehabilitation and Prevention. 2000;20(6):394.

34. de Jong N, Paw MJCA, de Groot LC, Rutten RA, Swinkels DW, Kok FJ, et al. Nutrientdense foods and exercise in frail elderly: effects on B vitamins, homocysteine, methylmalonic acid, and neuropsychological functioning. The American journal of clinical nutrition. $2 \quad-\quad:() \quad$;

35. Okura T, Rankinen T, Gagnon J, Lussier-Cacan S, Davignon J, Leon AS, et al. Effect of regular exercise on homocysteine concentrations: the HERITAGE Family Study. European journal of applied physiology. 2006;98(4):394-401.

36. Di Santolo M, Banfi G, Stel G, Cauci S. Association of recreational physical activity with homocysteine, folate and lipid markers in young women. European journal of applied physiology. 2009;105(1):111-8.

37. Mann DL, Zipes DP, Libby P, Bonow RO. Braunwald's heart disease: a textbook of cardiovascular medicine: Elsevier Health Sciences; 2014. 